\title{
„LECHOŃ W ALGIERZE”, CZYLI O PEWNEJ (NIEODEGRANEJ) ROLI DYPLOMATYCZNEJ $\mathbf{J}^{1}$
}

\section{Beata DOROSZ (Warszawa)}

Przedstawiony niżej zespół dokumentów archiwalnych — nigdy dotychczas niepublikowanych — stanowi korespondencja wymieniana w drugiej połowie 1943 roku między placówkami dyplomatycznymi Rzeczypospolitej Polskiej w Stanach Zjednoczonych (Ambasada RP w Waszyngtonie i Konsulat Generalny RP w Nowym Jorku) oraz rezydującym w Londynie Ministerstwem Spraw Zagranicznych rządu RP na uchodźstwie, a także przedstawicielstwem RP w Algierze, które powołano w 1943 roku przy kierowanym przez gen. Charlesa de Gaulle'a Komitecie Wyzwolenia Narodowego (przekształconym później w Tymczasowy Rząd Republiki Francuskiej).

„Pierwszoplanowym bohaterem” jest Jan Lechoń, przebywający wówczas od przeszło dwóch lat w Nowym Jorku, wobec którego czyniono plany aktywnego wykorzystania go w ówczesnej wojennej dyplomacji polskiej.

Inspiratorem tych działań był „bohater drugoplanowy” — Kajetan Dzierżykraj-Morawski, zawodowy polityk i dyplomata, którego z Lechoniem łączyła osobista przyjaźń, sięgająca dwudziestolecia międzywojennego. Choć w różnych okresach historii Polski - niepodległej, wojennej i emigracyjnej - był postacią znaczącą, nie jest powszechnie znany, warto więc przypomnieć podstawowe fakty z jego biografii.

${ }^{1}$ Tytuł niniejszego artykułu jest parafrazą tytułu słynnej opery Gioacchino Rossiniego Włoszka w Algierze (prapremiera: Wenecja 1813). Pierwotnie jego pomysł nasunął mi się niejako humorystycznie, tylko na zasadzie skojarzenia; okazuje się jednak, że może być uprawniony pół żartem, pół serio - także i ze względów merytorycznych, opisane w nim bowiem fakty korespondują (w przenośni) z treścią opery, której głównym wątkiem jest wyrażona przez władcę Algieru, Mustafę, gwałtowna potrzeba sprowadzenia tam (nawet siłą) atrakcyjnej kandydatki na żonę, najlepiej Włoszki, i perypetie jednej z nich, Izabeli, starającej się różnymi sposobami uniknąć tego losu. 
Urodził się 19 kwietnia 1892 roku w Jurkowie w Wielkopolsce w rodzinie ziemiańskiej. Studiował nauki rolnicze, prawo i ekonomię w Lipsku i Monachium. Po śmierci ojca w 1914 roku został właścicielem Jurkowa i objął zarząd majątku. Powołany w następnym roku do służby wojskowej w administracji niemieckiej, zajmował stanowisko rzeczoznawcy gospodarczego w jednym z powiatów w Wielkopolsce. Od 1 września 1918 roku pracował na kierowniczych stanowiskach w Departamencie Stanu rządu Rady Regencyjnej, przekształconym w październiku w Ministerstwo Spraw Zagranicznych. W 1919 roku jako członek Komitetu Przedplebiscytowego przygotowywał polską akcję plebiscytową na Warmii, Mazurach i Powiślu. Od 1920 roku zajmował wysokie stanowiska w centrali MSZ (m.in. w 1924 roku jako dyrektor Departamentu Politycznego). W latach 1923-1924 jako zastępca Komisarza Generalnego reprezentował Rzeczpospolitą Polską przy Wysokim Komisarzu Ligi Narodów w Gdańsku, pracując nad zharmonizowaniem uprawnień Polski i Wolnego Miasta Gdańska. W 1925 roku został mianowany ministrem-rezydentem RP przy Lidze Narodów w Genewie, a w maju następnego roku objął tekę ministra spraw zagranicznych w rządzie Wincentego Witosa. Po przewrocie majowym bezterminowo urlopowany ze służby dyplomatycznej, osiadł w Jurkowie, który stał się miejscem spotkań nie tylko wielkopolskiego ziemiaństwa, ale i ówczesnej elity intelektualnej i politycznej.

Najpewniej w tym czasie poznał Lechonia, o czym wspominał w szkicu Podzwonne:

Na wieś do mnie przywiózł go któregoś lata Baliński ${ }^{2}$. W starym domu, którego mury spatynowane były przeszłością i nasiąkłe poezją, czuł się dobrze. Zawarł przyjaźń z moimi dziećmi ${ }^{3}$, cieszył się, gdy wieczorem przed snem żądały od niego ,wierszyków”. Chętnie przeobrażał się dla nich w opowiadacza bajek w seraju padyszacha, nadwornego lutnistę z średniowiecznego zamczyska. Musiały słowa jego głęboko żłobić dziecinne umysły, bo ślad ich wpływu znajdowałem w wiele lat później w drukowanych w „Wiadomościach” wierszach mojej starszej córki Barbary Morawskiej-Ledóchowskiej ${ }^{4}$, i w poemacie z powstania warszawskiego napisanym przez młodszą, $\operatorname{Magdę}^{5}$ na kilka dni zanim poległa. Sam Leszek nie zapominał dawno minionych dni

${ }^{2}$ Mowa o Stanisławie Balińskim (1898-1984), poecie, prozaiku, krytyku literackim i teatralnym; z Morawskim łączyła go przede wszystkim praca w MSZ, ale zapewne nie bez znaczenia w tym środowisku było też jego ziemiańskie pochodzenie.

${ }^{3}$ Oprócz wymienionych dalej córek: Barbary i Magdaleny Morawski miał dwóch synów: Hieronima (1917-1985; przebywał na emigracji w Australii) i Macieja (ur. 1929; w powstaniu warszawskim goniec Polskiego Czerwonego Krzyża; od 1946 przebywał na emigracji, publicysta Radia Wolna Europa i działacz niepodległościowy).

${ }^{4}$ Barbara Maria Morawska-Ledóchowska (1921-2007) od 1939 przebywała z ojcem na Zachodzie; studiowała w London School of Economics. W 1946 wyszła za mąż za inżyniera Włodzimierza Ledóchowskiego (bratanka Matki Urszuli Ledóchowskiej, świętej Kościoła katolickiego) i wraz z rodziną osiadła w Republice Południowej Afryki, gdzie zajęła się działalnością na rzecz praw człowieka i dyskryminowanych przez politykę apartheidu czarnoskórych; współpracowała z biskupem Desmondem Tutu. W 1999 wyróżniona została nagrodą im. Brata Alberta; pod koniec życia powróciła do Polski. Wolno przypuszczać, że wspomniane przez Morawskiego wiersze drukowała w „Wiadomościach” pod pseudonimem, do 1956 bowiem (kiedy powstał cytowany szkic poświęcony Lechoniowi) nie figuruje wśród autorów publikujących w tym tygodniku.

5 Magdalena Maria Morawska (1922-1944), uczyła się w Poznaniu i w Rabce. Na początku wojny znalazła się w Warszawie, gdzie mieszkanie Morawskich służyło za konspiracyjny punkt kontaktowy i było schronieniem dla przybywających z Londynu ,cichociemnych”. Włączyła się do działalności podziemnej; została członkiem Konfederacji Narodu i żołnierzem Kedywu Komendy Głównej AK. Współpracowała również z tajnym pismem „Sztuka i Naród”. Ze względu na znakomitą znajomość jęz. francuskiego i niemieckiego jako rzekoma francuska volksdeut- 
letnich, bo jeszcze w r. 1942 przysłał mi z Nowego Jorku Lutnię po Bekwarku ,ze wspomnieniem Jurkowa, z pamięcią rozmów o poezji w szumie polskich drzew, z niezmożoną nadzieją powrotu tych chwil"6.

Poeta i dyplomata spotykali się też wielokrotnie u Anny i Tadeusza Jackowskich w wielkopolskim Wronczynie (które to miejsce i jego gospodarze odegrali w życiu Lechonia znaczące role, o czym po części dowiedzieć się można z jego z nimi korespondencji ${ }^{7}$ ), gdzie — jak wyznawał Morawski:

Wtenczas właśnie werbował mnie Leszek, od niedawna redaktor „Cyrulika Warszawskiego"8 na anonimowego i głęboko ukrytego, bo nieortodoksyjnego politycznie członka swego zespołu. Więcej wziął cięgów od cenzury niż zaoszczędził złotych w wyniku mej bezpłatnej współpracy ${ }^{9}$.

Morawski powrócił do aktywnej działalności politycznej w roku 1927 i w latach 1929-1931 w randze wiceministra był członkiem polsko-niemieckiej Komisji Mieszanej dla Górnego Śląska. Przeniesiony w 1934 roku w stan spoczynku, zajął się działalnością na polu gospodarczym, ale dwa lata później (1936) na wniosek ministra Eugeniusza Kwiatkowskiego został powołany na stanowisko wiceministra skarbu. We wrześniu 1939 roku ewakuował się wraz z rządem RP do Rumunii, gdzie po krótkim internowaniu zajmował się reorganizacją Ambasady RP w Bukareszcie.

W listopadzie 1939 roku dotarł do Paryża i objął kierownictwo Oddziału Politycznego w Biurze Badań Celów Wojny przy Rządzie Polskim. Tu ponownie spotkał Lechonia, który w stolicy Francji przebywał od kwietnia 1930 roku, dopiero jednak w maju następnego roku został formalnie pracownikiem Ambasady RP, oficjalnie zajmując stanowisko referenta prasowego, a faktycznie pełniąc funkcję attaché kulturalnego. Po wybuchu drugiej wojny światowej poeta okresowo prowadził w ambasadzie referat prasowy. Ewakuował się z Paryża w pierwszej połowie czerwca 1940 roku, w tym samym czasie co i organa uchodźczego rządu polskiego, a wraz z nimi i Morawski.

W sierpniu 1940 roku Lechoń opuścił Europę, udając się do Brazylii, a Morawski, odbywszy wędrówkę przez Hiszpanię i Francję (Vichy, Nicea), powrócił do Paryża, by

schka wykonywała zadania wywiadowcze w Hamburgu i Berlinie. W powstaniu warszawskim pełniła funkcję łączniczki dowódcy Zgrupowania „Radosław”; ranna 6 sierpnia 1944 na Woli, zmarła w Szpitalu Św. Jana Bożego. Informacje ojca o fascynacji Lechoniem potwierdza jej biogram na portalu internetowym Światowego Związku Żołnierzy Armii Krajowej - Okręg Wielkopolska, gdzie napisano m.in.: „Dobrze zapowiadająca się poetka pozostawała pod dużym wpływem twórczości i osoby Jana Lechonia. Mówiono nawet, że był jej pierwszą wielką, lecz nie spełnioną miłością". Poemat, o którym wspomina Morawski, nie był drukowany; jedyny ślad jej twórczości poetyckiej znalazł się kilka lat po wojnie w „Tygodniku Powszechnym” (1950 nr 9), gdzie wydrukowano jej wiersz Pielgrzym mówi..., datowany 25 czerwca 1944 i opatrzony krótką notą biograficzną autorki oraz informacją, że jej utwory nie były nigdzie publikowane.

${ }^{6}$ K. Morawski, Podzwonne, Wiadomości 1957 nr 23(584), s. 4; przedruk w: Pamięci Jana Lechonia, Londyn 1958, s. 29.

${ }^{7}$ J. Lechoń, Listy do Anny Jackowskiej, oprac. R. Loth, Warszawa 1977.

${ }^{8}$ Lechoń redagował satyryczny tygodnik „Cyrulik Warszawski” w 1926-1928, pismo wychodziło do 1934; rozgłos przyniosły mu Szopki polityczne, wystawiane pod jego auspicjami w 1927-1931, których autorami byli obok Lechonia M. Hemar, A. Słonimski, J. Tuwim, J. Paczkowski i Ś. Karpiński. Założone z inspiracji jednego z czołowych ideologów obozu sanacji, Adama Koca, do 1930 reprezentowało typ „satyry dworskiej”, popierającej politykę obozu piłsudczykowskiego, a zwalczającej antysanacyjną opozycję (zwłaszcza narodową demokrację), w późniejszym okresie miało charakter bardziej neutralny politycznie.

${ }^{9}$ K. Morawski, Podzwonne, s. 29. 
ostatecznie w lutym 1941 roku przez Hiszpanię i Portugalię przedostać się do Londynu, gdzie ponownie podjął pracę w dyplomacji. Początkowo kierował poselstwem RP przy emigracyjnym rządzie czechosłowackim Edvarda Beneša, później zajmował stanowisko sekretarza generalnego MSZ. W październiku 1943 roku wyjechał do Algieru i został akredytowany jako ambasador nadzwyczajny i poseł pełnomocny RP przy Komitecie Wyzwolenia Narodowego (późniejszym Tymczasowym Rządzie Republiki Francuskiej).

$\mathrm{Z}$ wydarzeniem tym wiąże się prezentowana tu archiwalna korespondencja, a pewne światło rzucają nań wspomnienia Morawskiego (z upływem lat wszakże różniące się nieco od faktów poświadczonych w dokumentach):

Objąwszy w r. 1943 ambasadę przy Francuskim Komitecie Wyzwolenia, zaproponowałem natychmiast Lechoniowi przyjazd do Algieru. Odpowiedział mi długim wywodem [zob. list nr 6], który czytałem z najwięekszym zdziwieniem. Dowodził, że zajmowanie się sprawami kulturalnymi już mu zbrzydło, że nęci go czysta polityka, że Claudel i Giraudoux byli szefami placówek dyplomatycznych, a nie przeszkodziło im to pisać, a nawet pisać świetnie. Zakończył nieoczekiwanym stwierdzeniem, że jedyne stanowisko, jakie by mu dogadzało, to poselstwo przy rządzie jugosłowiańskim.

Wybór Jugosławii był chyba zwykłym kaprysem jego wyobraźni. Że posiadał wyczucie polityczne - tego dowodzi choćby jego wiersz Z La Manczy ${ }^{10}$, jeden z najlepszych, jakie napisał w Ameryce, napięciem i tonacją przypominający Karmazynowy poemat, a rysujący de Gaulle'a na tle dzisiejszej Francji o tyle wyraźniej i prawdziwiej niż arcydzieła nieporozumień, jakie błyskotliwą prozą kreślił równocześnie na łamach „Wiadomości” Stanisław Mackiewicz ${ }^{11}$. Wyczucie nie przemieniało się jednak u niego w namiętne zainteresowanie, a pasja, jaka istotnie ogarnęła Lechonia-obywatela, Lechonia-emigranta wyrosła z podłoża patriotycznego, a nie politycznego. Chęć zaś objęcia placówki dyplomatycznej była typowym płodem jego drugiego, zewnętrznego kręgu życiowego, była oglądaniem się za nowym tłem, nie za nową treścią. A może stawiając żądanie trudne do ziszczenia szukał podświadomie pretekstu, by móc zostać za oceanem? ${ }^{12}$

O Lechoniu i odrzuconej przez niego propozycji będzie dalej mowa. Wróćmy jeszcze do Morawskiego, który w tym samym charakterze co w Algierze pracował w 1944 roku w Paryżu po wyzwoleniu Francji spod okupacji niemieckiej. Po zakończeniu wojny odrzucił propozycję reżimu warszawskiego, by kontynuować służbę dyploma-

${ }^{10}$ Pierwodruk: Wiadomości 1953 nr 30(382). Z notatek Lechonia w Dzienniku (cyt. za: J. Lechoń, Dziennik, t. 3, Warszawa 1993) wynika, że wiersz powstał w ciągu dwóch dni (zapewne pod wpływem wiadomości, że po porażce ruchu de Gaulle'a w wyborach samorządowych 1953 ogłosił on wycofanie się z życia politycznego i publicznego): „Napisać wiersz o de Gaulle'u — o krzyżu lotaryńskim, o wiatrakach — że niby on, ten tragiczny Donkiszot" [ 25 czerwca 1953, s. 149]. „Napisałem bez większego namysłu, w jakieś pół godziny cztery zwrotki o de Gaulle'u, które będą się nazywały Z La Manczy. Najbardziej klasycznie [...]” [26 czerwca 1953, s. 150]. Notatki z następnych lat poświadczają jednak zmianę stosunku poety do francuskiego polityka, głównie w wyniku lektury jego pamiętników, drukowanych na łamach „Paris Match”, które dowodziły niezrozumienia przez niego historii i problemów Polski, przede wszystkim zaś niedocenienia roli J. Piłsudskiego [13 października 1954, s. 480], aczkolwiek były literackim arcydziełem [27 listopada 1955, s. 737]. Widząc współczesność Francji wyłącznie w kategoriach upadku i konieczności odrodzenia jej „duszy”, Lechoń pisał (co warto podkreślić — nawet bardzo niedługo przed samobójczą śmiercią komentując sprawy polityczne): „Tak jak się dziś wydaje, musi przyjść na jakiś czas de Gaulle, ale co do mnie, to ponieważ tak go sobie kiedyś wymarzyłem — teraz nie mam żadnych co do niego złudzeń” [20 maja 1956, s. 847].

${ }^{11}$ Mowa o Stanisławie Mackiewiczu (1896-1966), publicyście politycznym, od wybuchu wojny przebywającym na emigracji, który w 1954-1955 pełnił funkcję premiera rządu RP na uchodźstwie, a w czerwcu 1956 powrócił do Polski.

${ }^{12}$ K. Morawski, Podzwonne, s. 31 
tyczną jako jego przedstawiciel. Pozostał na emigracji w Paryżu; jako aktywny działacz Polonii opiekował się polskimi instytucjami kulturalnymi (m.in. był członkiem zarządu Biblioteki Polskiej w Paryżu i pełnił funkcję wiceprezesa Towarzystwa Historyczno-Literackiego we Francji) oraz prowadził polityczne akcje niepodległościowe. W 1956 roku przewodniczył paryskiemu komitetowi organizacyjnemu (obok analogicznych w Nowym Jorku i Londynie) Kongresu Wolnej Kultury Polskiej, który planowano na czerwiec w Paryżu, z udziałem Lechonia jako głównego mówcy inaugurującego obrady; (kongres, początkowo przeniesiony na wrzesień, nigdy nie doszedł do skutku, poeta zaś w czerwcu popełnił samobójstwo). Przez wiele lat Morawski związany był z Radiem Wolna Europa. W polskich czasopismach emigracyjnych, głównie w londyńskich „Wiadomościach”, publikował wspomnienia, artykuły literackie i fragmenty prozy. Był członkiem Międzynarodowego PEN Clubu. Wydał cztery prozatorskie tomy wspomnieniowe: Tamten brzeg (Paryż 1960; tu przypomniał tekst poświęcony Lechoniowi), Wspólna droga (Paryż 1962), Wczoraj. Pogadanki o niepodlegtym dwudziestoleciu (Londyn 1967) i Na przełaj (Londyn 1969). Zmarł 2 listopada 1973 roku w Domu Polskim w Lailly-en-Val i tam został pochowany.

Wypada zająć się teraz wspomnianym listem Lechonia do Morawskiego, opisanymi przez niego faktami i użytymi argumentami, które miały uzasadnić ostateczną odmowę poety przyjęcia proponowanego mu stanowiska.

Najistotniejszą kwestią była dla niego jego własna twórczość — z trudem odradzająca się po wieloletnim okresie milczenia, które oceniał nader krytycznie: ,jeśli nie straciłem dla mego «rozwoju» tych dziesięciu lat w Paryżu — to w każdym razie nie zdołałem przez ten czas nic napisać". Rozwinął się zapewne w tym okresie świetnie, nawiązując rozliczne i przyjacielskie kontakty z francuską elitą intelektualną, później jednak mówił o „zmarnowanych latach życia” i „ze zgrozą myślał, ile lat przegadał z tymi salonowymi durniami""13, choć była to niewątpliwie wielka kariera towarzyska, budząca tak podziw, jak i zazdrość postronnych obserwatorów. (Wolno przypuszczać, że ewentualność wykorzystania niektórych z tych koneksji w warunkach dyplomacji wojennej czyniła Lechonia atrakcyjnym dla rządu pracownikiem; o kilku z nich wspomina zresztą w tym kontekście i sam poeta). W owym czasie zabiegał Lechoń przede wszystkim o promowanie kultury polskiej we Francji, a ukoronowaniem tych starań było wystawienie w kwietniu 1936 roku w Operze Paryskiej Harnasiów Karola Szymanowskiego. Z rzadka pisywał artykuły do warszawskiej „Gazety Polskiej”, relacjonujące francuskie wydarzenia kulturalne lub odnoszące się do aktualnych stosunków polsko-francuskich. Ale wierszy nie pisał prawie wcale — paradoksalnie, właśnie w tym mieście żyjącym kulturą i sztuką, czuł się wypalony emocjonalnie, zniewolony intelektualnie, niezdolny do kontynuowania własnej twórczości. Wstrząs, jakim był wybuch wojny, a później nowe realia emigracyjne w Stanach Zjednoczonych, gdzie przebywał od sierpnia 1941 roku, obudziły w nim na nowo potrzebę twórczości. Pierwszym tego wyrazem był wydany w 1942 roku tom wierszy Lutnia po Bekwarku, wspomniany przez Morawskiego.

Na własną twórczość literacką pozostawało mu wszakże znów zbyt mało czasu, bo w okresie, kiedy padła propozycja ponownego zaangażowania się w służbę dyplomatyczną, najbardziej absorbującym go wyzwaniem był „Tygodnik Polski”, którego pierwszy numer ukazał się 10 stycznia 1943 roku. Jakkolwiek członkami redakcji byli obok niego Zenon Kosidowski, Kazimierz Wierzyński i do połowy 1943 roku także Józef Wittlin, ciężar prowadzenia pisma — zarówno w kwestiach merytorycznych, jak

\footnotetext{
${ }^{13}$ J. Lechoń, Dziennik, t. 3, s. 221 [2 października 1953].
} 
i organizacyjno-finansowych — spoczywał głównie na Lechoniu. Ogłosił tu kilka nowych wierszy, ale przede wszystkim opublikował olbrzymią liczbę artykułów publicystyczno-politycznych i literackich, w tym także mnóstwo anonimowych, drukowanych w imieniu redakcji. Pismo miało od początku określony profil polityczny, w którym istotna była kwestia niezmienności polskich granic (powrót Wilna i Lwowa), potępienie deportacji Kresowiaków w głąb Rosji, domaganie się wyjaśnienia sprawy grobów katyńskich. Jakkolwiek „Tygodnik” finansowany był z funduszy przydzielonych przez rząd londyński, redakcja była zasadniczo w opozycji do rządowej polityki zagranicznej, ocenianej ogólnie jako ugodowa, a wobec Związku Sowieckiego szczególnie ustępliwa. W konsekwencji takiej postawy z końcem roku 1943 rząd, decyzją ówczesnego ministra informacji i dokumentacji, Stanisława Kota ${ }^{14}$, cofnął subwencję na wydawanie pisma; (od tego też momentu pozostała Lechoniowi nigdy niewygasła niechęć do ówczesnego ministra-decydenta). Od początku 1944 roku aż do końca istnienia, tj. do czerwca 1947 roku, „Tygodnik” mógł ukazywać się wyłącznie dzięki prenumeratom i prywatnym donacjom, o które zabiegać musiał jedyny już wówczas redaktor — Lechoń.

Opozycyjny wobec rządu jako redaktor i wydawca „Tygodnika”, był Lechoń jednak cenionym i poszukiwanym przez organa rządowe współpracownikiem na niwie propagandy polskości. Stosunkowo szybko po przyjeździe do Stanów Zjednoczonych znalazł bowiem zajęcie w Polish Information Center ${ }^{15}$; do najbardziej prestiżowych należały wówczas m.in.: pisanie po francusku na zamówienie rządu książki o Polsce pod roboczym tytułem Tradycje nowoczesności, która miała być wykorzystywana w celach propagandowych ${ }^{16}$; opracowanie $\mathrm{z}$ polecenia ambasady RP w Waszyngtonie dla amerykańskiego War Department serii audycji radiowych na temat Polski, przeznaczonych do nauczania żołnierzy amerykańskich o historii i tradycji narodów sprzymierzonych $^{17}$; pisanie na zamówienie ówczesnego szefa PIC, Stefana Roppa ${ }^{18}$, „,małej

${ }^{14}$ Stanisław Kot (1885-1975), historyk, działacz ruchu ludowego, polityk, wychowawca. Od 1920 był profesorem Uniwersytetu Jagiellońskiego (w 1933 pozbawiony katedry, m.in. za protest przeciw uwięzieniu przywódców Centrolewu), od 1921 - członkiem Polskiej Akademii Umiejętności. Od 1933 działał w Stronnictwie Ludowym, był też działaczem opozycyjnego Frontu Morges. We wrześniu 1939 wszedł jako wicepremier do rządu gen. W. Sikorskiego, włączając się do „oczyszczania” armii z ludzi związanych z sanacją. W 1941-1942 był ambasadorem RP w ZSRR, w 1942-1943 ministrem stanu na Bliskim Wschodzie, w 1943-1944 ministrem informacji. W lipcu 1945 powrócił do kraju i z ramienia Tymczasowego Rządu Jedności Narodowej był w 1945-1947 ambasadorem w Rzymie. W 1947 ponownie wybrał emigrację i od 1955 pełnił funkcję przewodniczącego Rady Naczelnej Polskiego Stronnictwa Ludowego na obczyźnie.

${ }^{15}$ Polish Information Center (PIC) - agenda Ministerstwa Informacji i Dokumentacji rządu RP na uchodźstwie, założona w 1940 w Nowym Jorku dla informowania społeczności amerykańskiej o sytuacji w okupowanej Polsce, działalności rządu polskiego, walce AK w kraju i udziale Polskich Sił Zbrojnych na Zachodzie w kampaniach aliantów. Placówka służyła też pomocą naukowcom i artystom polskim, przebywającym w Stanach Zjednoczonych, m.in. wypłacając stypendia rządowe z Funduszu Kultury Narodowej. Działała do połowy 1945, tj. do cofnięcia przez Stany Zjednoczone uznania rządowi polskiemu na emigracji.

${ }^{16}$ Jest o tym mowa m.in. w liście J. Lechonia do S. Strońskiego z 15 lipca 1941; Hoover Institution, Ministerstwo Informacji i Dokumentacji, sygn. box 76 / folder 5.

${ }^{17}$ Informacja za: Archiwum Akt Nowych, kolekcja 490, Ambasada RP w Waszyngtonie, teczka 2759.

${ }^{18}$ Stefan de Ropp (1892-1983), baron, inżynier metalurgii i górnictwa, bankowiec; w 19261938 profesor Wyższej Szkoły Handlowej w Poznaniu. W 1939 był komisarzem generalnym polskiego pawilonu na Wystawie Światowej w Nowym Jorku. W 1940 wykładał ekonomię na Fordham University w Nowym Jorku. W 1940-1943 był dyrektorem Polish Information Center, a w 1944-1945 - szefem Office of Research and Publication (oddział PIC). Po wojnie pracował 
encyklopedii” o Polsce, którą zamierzano wydać po hiszpańsku ${ }^{19}$. (Bibliografia Lechonia nie odnotowuje wspomnianych tu książek, aczkolwiek zachowane archiwalia potwierdzają, że poeta istotnie nad nimi pracował; nie można więc do końca wykluczyć, że projektowane jako druki o charakterze propagandowym — w czasie wojennym zapewne raczej broszury niż książki — mogły być wówczas wydane anonimowo.) Mając poczucie własnej wartości, o tych aktualnych poczynaniach na terenie amerykańskim Lechoń pisał Morawskiemu: „Ja tutaj czasu nie tracę, nie tylko pisząc, ale i ucząc się też zupełnie dotąd obcego świata i nieznanych ludzi”. Choć zajęty ponad miarę i zatroskany w tych okolicznościach przede wszystkim o możliwość pracy twórczej, deklarował mimo to ambasadorowi: „nie mam prawa i nie chcę odmawiać rządowi tych usług, które naprawdę byłyby ważne i w których mógłbym być niezastąpiony”.

Zawsze żywo zainteresowany polityką i na swój sposób działający na jej obrzeżach (czego świadectwem mógł być choćby profil redagowanego przez niego „Cyrulika Warszawskiego", autorstwo szopek politycznych, a jeszcze wcześniej przed nimi trzy tomy politycznych satyr wierszem i prozą ${ }^{20}$ ), także w czasach nowojorskich pochlebiał sobie, że mógłby być cennym współpracownikiem w dyplomacji, gdyż czuł się doskonale obznajmiony z bieżącą polityką. Gdy pisał Morawskiemu: ,znam sprawy francuskie z najważniejszego teraz dla nich punktu to znaczy się z Waszyngtonu”, mógł się zapewne odwołać do wiedzy czerpanej z częstych spotkań i poufnych rozmów odbywanych z polskimi przyjaciółmi-politykami, działającymi na różnych forach, tak polskich, jak i amerykańskich, ale istotnie w samym centrum decyzyjnym, czyli w Waszyngtonie. Zaliczali się do nich przede wszystkim Jan Ciechanowski ${ }^{21}$, ówczesny ambasador RP w Waszyngtonie, Jan Wszelaki ${ }^{22}$, radca w tejże ambasadzie, czy wreszcie Władysław

na amerykańskich uczelniach (m.in. Columbia University) jako wykładowca historii, języka i literatury rosyjskiej.

${ }^{19}$ Wspomina o tym S. Ropp w liście do S. Strońskiego z 12 marca 1942; Hoover Institution, Ministerstwo Informacji i Dokumentacji, sygn. box 76 / folder 6 .

${ }^{20}$ J. Lechoń, Królewsko-Polski kabaret 1917-1918, Warszawa 1918; tenże, Facecje republikańskie, Warszawa 1919 (współaut.: A. Słonimski); tenże, Rzeczpospolita Babińska. Śpiewy historyczne, Warszawa 1920.

${ }^{21}$ Jan Ciechanowski (1887-1973), dyplomata; po studiach inżynierskich w Karlsruhe i ekonomicznych w Birmingham pracował w instytucjach bankowo-giełdowych w Londynie; w 1918 podjął pracę w dyplomacji, a w następnym roku został sekretarzem I. J. Paderewskiego. Przez dziesięć kolejnych lat piastował ważne funkcje na placówkach dyplomatycznych w Londynie i w Waszyngtonie. W 1929-1939 zwolniony ze służby dyplomatycznej, został reaktywowany po klęsce wrześniowej i objął stanowisko sekretarza generalnego MSZ w Angers i w Londynie. W 1941-1945 pełnił funkcję ambasadora RP w Waszyngtonie. Po wojnie pozostał na emigracji. Z Lechoniem związany był przyjaźnią; na początku 1941, wraz z kilkoma innymi osobami, czynił starania o wizę amerykańską dla poety, przebywającego wówczas w Brazylii; w 1949 wraz z Janem Wszelakim zabiegał o zaangażowanie Lechonia na stałym etacie w nowo utworzonym wówczas National Committee for Free Europe.

${ }^{22}$ Jan Wszelaki (1894-1965), dyplomata. Studiował w Moskwie i w Paryżu. Od 1918 był pracownikiem MSZ, zajmując wysokie stanowiska w centrali oraz na placówkach w Moskwie i Londynie. W czasie wojny najpierw w Angers, potem w Londynie sprawował funkcję sekretarza generalnego MSZ, następnie radcy Ambasady RP w Waszyngtonie. Po wojnie pozostał na emigracji i był przedstawicielem dyplomatycznym rządu polskiego na uchodźstwie, czynnie zaangażowanym w działalność niepodległościową. Doktoryzował się na Georgetown University w Waszyngtonie, po czym wykładał tamże na American University. W 1962 został dyrektorem Polskiego Instytutu Naukowego w Nowym Jorku. Lechoń traktował dom Marii i Jana Wszelakich w Waszyngtonie nieomal jak dom rodzinny i bywał tam bardzo częstym gościem. 
Besterman $^{23}$, attaché prasowy ambasady. Głęboko rozczarowany postawą polskich sojuszników, Anglii i Francji, we wrześniu 1939 roku i potępiający Francję za jej błyskawiczną kapitulację w czerwcu 1940 roku, uznawał, że tylko w Ameryce mogą zapadać decyzje, które w rzeczywisty sposób wpływają na losy wojny i politykę światową.

W liście do Morawskiego nie po raz pierwszy dawał Lechoń wyraz głębokiemu przekonaniu, że „teraz parę zadań dyplomatycznych powinni wziąć na siebie poeci” i nie bez przyczyny sugerował, że ,gdyby Rzeczpospolita posłała go jako posła z Rządem Jugosłowiańskim, zrobiłaby dobry interes”. Uwaga ambasadora, że „wybór Jugosławii był chyba zwykłym kaprysem jego wyobraźni”, nie do końca była słuszna, poeta uczestniczył bowiem już wcześniej w działaniach polsko-jugosłowiańskiej emigracyjnej dyplomacji, reprezentując 9 lipca 1942 środowisko pisarzy polskich na spotkaniu Komitetu Narodowego Amerykanów Polskiego Pochodzenia ${ }^{24}$ z przebywającym wówczas w Stanach Zjednoczonych królem Jugosławii Piotrem II $^{25}$. Polityczne spotkanie, w którym wziął oficjalny udział także ambasador Ciechanowski, zdominowały wypowiedzi porównujące dzieje Jugosławii z historią Polski, król zaś wygłosił przez radio przemówienie adresowane do żołnierzy polskich rozproszonych na wszystkich frontach toczącej się wojny, podkreślając solidarność w walce i wspólnotę interesów obu narodów. Wystąpienie poety na zakończenie uroczystości, pełne patetycznych słów o „,popiołach Belgradu i ruinach Warszawy”, wyrażało wspólne dla wszystkich życzenie sprawiedliwości i zwycięstwa ${ }^{26}$. Najwyraźniej powodowany nie tylko względami natury politycznej, ale pod wrażeniem spotkania z młodziutkim monarchą, krótko potem ogłosił Lechoń artykuł, w którym była mowa o ,pięknej i homerycko potężnej historii Jugosławii” i o Piotrze II, który ratując honor, „,w jednym dniu z dziecka stał się mężem, aby poprowadzić swój naród do zwycięstwa”, jednocześnie stając się ,ppostacią z legendy" 27 .

${ }^{23}$ Władysław Besterman (1903-1974), dyplomata. Przed wojną pracował w Agencji Iskra, a w czasie wojny jako attaché prasowy Ambasady RP w Waszyngtonie. Po wojnie był wysokim urzędnikiem Kongresu USA; pracował w Committee on Immigration and Naturalization przy Izbie Reprezentantów, był stałym doradcą Komisji Prawniczej i głównym doradcą Komisji do Badania Spraw Uchodźców. Odegrał istotną rolę w zabiegach Lechonia o naturalizację, kierując przy pomocy zaprzyjaźnionych urzędników amerykańskich kolejnymi ich etapami.

${ }^{24}$ Komitet Narodowy Amerykanów Polskiego Pochodzenia (KNAPP), organizacja Polaków w Stanach Zjednoczonych, powstała w 1942 z inicjatywy piłsudczyków (I. Matuszewskiego, H. Floyar-Rajchmana, W. Jędrzejewicza, i B. Wieniawy-Długoszowskiego) i działała do 1959. Środowisko KNAPP, oskarżając rząd RP na uchodźstwie - reprezentowany przez premierów W. Sikorskiego i S. Mikołajczyka - o politykę ugodową wobec ZSRR i naiwność wobec polityki aliantów zachodnich, występowało w obronie interesów polskich, zwłaszcza idei niepodległości i integralności terytorialnej Rzeczypospolitej, oraz podejmowało działania na rzecz dotrzymania gwarancji wynikających z Karty Atlantyckiej i układu sojuszniczego RP z Wielką Brytanią z sierpnia 1939. Działalność i idee KNAPP były propagowane na łamach „Tygodnika Polskiego” redagowanego przez Lechonia, który pisywał też do „Biuletynu Organizacyjnego KNAPP”; uczestniczył m.in. w opracowaniu „Deklaracji Ideowej KNAPP”, przyjętej na zjeździe inauguracyjnym w czerwcu 1942, oraz redagował złożony w Białym Domu w maju 1942 apel do prezydenta F. D. Roosevelta o ,zachowanie świętości granic Polski, jakimi były w 1939 roku”.

${ }^{25}$ Piotr II Karadziordziewić (1923-1970), król Jugosławii w 1934-1945; w 1941 uszedł przed niemiecką inwazją do Wielkiej Brytanii; faktycznie zdetronizowany po proklamowaniu w październiku 1945 Federacyjnej Ludowej Republiki Jugosławii.

${ }^{26}$ Obszerna relacja ze spotkania oraz teksty wystąpień Piotra II i Lechonia znalazły się na łamach nowojorskiego „Nowego Świata” (10.07.1942, s. 1, 3): Król Jugosławii do żotnierzy polskich... oraz mowa Jana Lechonia do króla Piotra II.

${ }^{27}$ J. Lechoń, Na powitanie króla, Nowy Świat (Nowy Jork) 12.07.1942, s. 9, 10. 
Nie bez znaczenia też wydaje się fakt, że krótko przed napisaniem listu do Morawskiego Lechoń ogłosił na łamach „Tygodnika Polskiego” artykuł Prestiż i federacja ${ }^{28}$, w którym kreślił własną wizję powojennej Europy. Oparta była na idei federacji „,narodów Centralnej i Wschodniej Europy”, mającej zapewnić im „prawdziwą niepodległość, bezpieczeństwo i wolny rozwój”, ale stanowiącej jeden „organizm państwowy, którego wojsko i polityka zagraniczna broniłyby zarówno każdego z tych sfederowanych narodów”. Odwoływał się przy tym do historii Polski z okresu jej „,mocarstwowości” w głębokim przekonaniu, że „,była to federacja właśnie, że cały okres tej polskiej świetności jest to okres najściślejszego związku Polski, Litwy i Rusi, i czasowych połączeń z dzisiejszymi Bałtami, Czechami, Węgrami i Wołochami, ojcami dzisiejszych Rumunów”. Dowodził też, że wizja Polski fanatycznie uwielbianego przez niego marszałka Piłsudskiego była w istocie wizją państwa federacyjnego. Przekonywał, że tragedia wojny, która w równym stopniu dotknęła Polaków, Czechów, Serbów i Greków jest nauką i ,wezwaniem nie tylko do nas, ale i do wszystkich, abyśmy się połączyli”. W jego koncepcji rola rzeczywistego twórcy owej federacji przypadała rzecz jasna Polsce, ale zakładał, że „kto naprawdę wierzy w Polskę, tego nie powinna zadziwić myśl, że w nowym wielkim państwie mógłby być na przykład król Jugosławii naczelną osobą, a powiedzmy jakiś grecki mąż stanu kanclerzem”.

Niezależnie od tego, jak dalece była to wizja utopijna, mogła jednak w pewnym stopniu wpływać na decyzję Lechonia, by pozostać w „orbicie politycznej” kręgu Jugosławii i zachować dystans wobec zaangażowania w relacje polsko-francuskie. (Dziś należałoby tę koncepcję ocenić raczej w kategoriach nieomal fantastycznego marzenia poetyckiego, nie mającego nic wspólnego z ówczesnymi realiami politycznymi; warto jednak pamiętać, że idea federalizmu miała też innych wyznawców, co zaowocowało powołaniem w 1950 roku Związku Polskich Federalistów w Stanach Zjednoczonych, którego Lechoń był członkiem-założycielem, a od 1951 wchodził w skład jego Rady.)

Mając na uwadze cały skomplikowany konglomerat spraw i problemów, z którymi mierzył się w owym czasie Lechoń, oraz znając poziom jego wrażliwości i osobistych emocji w ocenie własnej sytuacji, a także stan oczekiwań wobec własnej przyszłości, trudno dziś znaleźć jednoznaczną odpowiedź na pytanie, dlaczego naprawdę poeta nie przyjął proponowanego mu dyplomatycznego stanowiska. Prawdziwe motywy rezygnacji (lub też raczej pozorowanego odsunięcia decyzji na bliżej nieokreśloną przyszłość) pozostają nieznane - czy byłoby to pragnienie rozwoju własnej twórczości i niechęć do utrudniających ją nowych obowiązków, czy troska o przyszłość „Tygodnika Polskiego", czy wynikające z wcześniejszych doświadczeń zniechęcenie do ,światowości” i służby dyplomatycznej, czy obawa przed opuszczeniem stosunkowo bezpiecznych Stanów Zjednoczonych i znalezienie się w strefie działań wojennych, czy wreszcie może powody natury osobistej, o których tu nigdzie przecież nawet nie napomknięto. Gdy pamięta się zaś osiągnięcia Lechonia jako radcy kulturalnego z przedwojennego Paryża oraz jego zaangażowanie w działania polityczno-propagandowe i niepodległościowe w Stanach Zjednoczonych (z których tylko nieliczne tu wspomniano), pozostaje też otwarte pytanie, ile na jego odmowie wyjazdu do francuskiego Algieru istotnie straciła dyplomacja polska.

\footnotetext{
${ }^{28}$ Tenże, Prestiż i federacja, Tygodnik Polski (Nowy Jork) 1943 nr 32, s. 1.
} 
Prezentowane poniżej dokumenty publikowane są po raz pierwszy ${ }^{29}$.

Dla potrzeb niniejszej edycji poprawiono ortografię i interpunkcję oraz uwspółcześniono końcówki fleksyjne; liczebniki zapisane w oryginale cyfrą zamieniono na wyrazowe (10 lat = dziesięć lat).

W trudno czytelnym rękopiśmiennym liście Lechonia wątpliwe odczytania oznaczono [?], zaś słowa niemożliwe do odczytania [---].

\section{LISTY}

1.

Telegram Szyfrowy Odchodzacy: do Polmission Waszyngton [Ambasady RP w Waszyngtonie] z Ministerstwa Spraw Zagranicznych [rzadu RP na uchodźstwie w Londynie], datowany 6 lipca 1943; opatrzony numerem 435; maszynopis na drukowanym formularzu.

Na dokumencie u góry odręczny dopisek: Lechoń, a w innym miejscu oznaczenie: L. 14.

Proszę zapytać Radcę Lechonia, czy ewentualnie przyjąłby stanowisko radcy dla spraw prasowych przy przedstawicielstwie politycznym w Algierze (Ambasada na Francję). Przewiduję konieczność wyjazdu w ciągu lipca. Proszę pilnie telegraficzną odpowiedź.

Raczyński $^{30}$

\section{2.}

Telegram Szyfrowy Przychodzacy: z Polmission - Washington do Ministerstwa Spraw Zagranicznych, wystany 7 lipca 1943, otrzymany 8 lipca 1943; opatrzony numerem 355; maszynopis na drukowanym formularzu.

Na dokumencie u góry odręczny dopisek: Lechoń.

Receptus ${ }^{31}$ No 435 [tu odręczny dopisek] (Lechoń).

W sprawie Lechonia.

L. przyjął propozycję. Proszę telegraficznie instrukcje.

Ciechanowski

${ }^{29}$ Listy oznaczone numerami 1-5 oraz 7-13 pochodzą z kolekcji Ministerstwa Spraw Zagranicznych w Muzeum gen.. Sikorskiego w Londynie (sygn.: MSZ, Jan Lechoń, A. 11.474/2/393], list 6 (J. Lechonia do K. Morawskiego) ze zbiorów Kajetana Dzierżykraj-Morawskiego z Biblioteki Polskiej w Paryżu (sygn. 1.101 — wg Przewodnika po zespołach rękopisów Towarzystwa Historyczno-Literackiego i Biblioteki Polskiej w Paryżu, ParyżWarszawa 2000).

${ }^{30}$ Edward Raczyński (1891-1993) był wówczas ministrem spraw zagranicznych. Dyplomata; w 1919-1926 pracował jako sekretarz poselstwa RP w Kopenhadze i w Londynie, po czym do 1932 zajmował wysokie stanowiska w centrali MSZ; w 1932-1934 był delegatem RP przy Lidze Narodów w Genewie w randze posła nadzwyczajnego i ministra pełnomocnego; następnie do 1945 był ambasadorem w Londynie, pełniąc jednocześnie funkcję ministra spraw zagranicznych (w okresie od 28 sierpnia 1941 do 4 lipca 1943 w rządzie gen. W. Sikorskiego, a od 4 lipca 1943 do 14 lipca 1943 w rządzie pełniącego obowiązki premiera S. Mikołajczyka) oraz ministra stanu (1942-1945); po wojnie pozostał na emigracji, w 1979-1986 piastował godność prezydenta RP na uchodźstwie.

31 (łac.) dosłownie - odebranie; tu - dotyczy. 


\section{3.}

Telegram Szyfrowy Odchodzacy: do Polmission Waszyngton z Ministerstwa Spraw Zagranicznych, datowany 16 lipca 1943; opatrzony numerem 463; maszynopis na drukowanym formularzu. Na dokumencie w różnych miejscach odręczne dopiski: Lechoń, L - 14, L - 14/43.

\section{Receptus 355.}

Sprawa budżetu przedstawicielstwa politycznego w Algierze będzie wkrótce zdecydowana przez Radę Ministrów. O ile Rada Ministrów zatwierdzi etat radcy dla spraw prasowych, powiadomimy niezwłocznie Lechonia.

Raczyński

\section{4.}

Telegram Szyfrowy Odchodzacy: do Polconsul New York [Konsulatu Generalnego RP w Nowym Jorku] z Ministerstwa Spraw Zagranicznych, datowany 6 września 1943; opatrzony numerem 154; maszynopis na drukowanym formularzu.

Proszę zapytać się Lechonia, czy zgadza się na objęcie stanowiska radcy prasowego w Ambasadzie na Francję i czy może przybyć na 1-go października wprost do Algieru.

Morawski

Pod tekstem dwie odręczne notatki z nieczytelnymi podpisami:

Expediatur p. min. Morawskiego ${ }^{32}$

3.9.43.

Po wysłaniu: P.I. do wiad[omości].

\section{5.}

Telegram Szyfrowy Odchodzacy: do Polconsul New York z Ministerstwa Spraw Zagranicznych, datowany 18 września 1943; opatrzony numerem 171; maszynopis na drukowanym formularzu.

Refero $^{33} 154$.

Proszę przyśpieszyć odpowiedź.

Morawski

Pod tekstem odręczna notatka z nieczytelnym podpisem:

Expediatur p. min. Morawskiego

16.9.43.

${ }^{32} \mathrm{Z}$ łac.: polecenie wysłania wydane przez p. min. Morawskiego. Chodzi o procedury związane z oficjalną korespondencją dyplomatyczną (zapewne dodatkowo sformalizowane ze względu na konieczność szyfrowania): treść depeszy była przedstawiana najpierw w rękopisie (w archiwum zachował się również i ten dokument), a przepisanie jej na maszynie i faktyczne wysłanie następowało w ciągu 2-3 dni, tj. Morawski napisał depeszę 3 września, która w zaszyfrowanej formie była wysłana 6 września 1943. Zob. też telegram następny (nr 5), napisany przez Morawskiego 16 września, a wysłany 18 września 1943.

33 (lac.) tu - w odpowiedzi. 


\section{6.}

List Jana Lechonia z Nowego Jorku do Kajetana Dzierżykraj-Morawskiego w Londynie; trzy arkusze formatu ca. A4, zapisane jednostronnie; rękopis na papierze firmowym „Tygodnika Polskiego”.

Nowy Jork 14 września 1943

Mój drogi!

Przepraszam Cię najmocniej, że nie odpowiedziałem od razu depeszą na formalną depeszę Ministerstwa, ale w żaden sposób nie zdołałem wyrazić telegraficznie tylu rzeczy, które powiedzieć muszę i od których moja decyzja zależy. Przepraszam też, że to nie jest maszynopis tylko rękopis, ale nie chciałem, przyznam się, powierzać nikomu tego, co tu piszę.

Przede wszystkim jednak chciałem Ci najserdeczniej powinszować Twojej godności Ambasadorskiej, którą jak pamiętasz, pisząc, Cię obdarzyłem w mej dedykacji ${ }^{34}$. Nie potrzebuję chyba rozwodzić się nad tym, że wybór naszego Wodza [?] ${ }^{35}$ wydaje mi się znakiem jego szczęśliwej mądrości i przenikliwości i że naprawdę nie wyobrażam sobie, jak można by roztropniej w tej sprawie postąpić.

Przechodząc do mojej sprawy, to wiesz prawdopodobnie, na dawną, sprzed paru jeszcze miesięcy depeszę, napisaną przez Raczyńskiego, a zakomunikowaną mi telegraficznie z Waszyngtonu przez Ciechanowskiego, odpowiedziałem od razu i bezwarunkowo pozytywnie, naprawdę obywatelskim odruchem i odruchem serca wobec sprawy, w której dziesięć lat życia „strawiłem” (to powiedzenie jest bardzo ścisłe, jeśli chodzi o Paryż). Od tego czasu, kiedy mowa była o wyjeździe, musiałem zastanowić się sumiennie, co czynię — i rozważając pro mojej użyteczności w tej pracy i contra - ewentualnych strat, jakie ponieść by na tym mogła moja $\mathrm{z}$ takim trudem odnowiona i dochodząca do formy twórczość oraz swoboda osobista - doszedłem do takich oto wniosków, jak zobaczysz, niełatwych do wyrażenia depeszą.

Mam Cię, Mon Cher Ambassadeur et Ami ${ }^{36}$, za prawdziwego przyjaciela i zwłaszcza bardzo łaskawego i czułego czytelnika; to więc, co byłoby może zupełnie nieistotne dla Ministerstwa, Tobie powierzam, abyś to łaskawie wziął na swoje sumienie i był, jeśli chcesz być tak dobry, rzecznikiem tej sprawy u góry, czy mówiąc z tą „górą” mową już niejako urzędową.

Jak wiesz — jeśli nie straciłem dla mego „rozwoju” tych dziesięciu lat w Paryżu — to w każdym razie nie zdołałem przez ten czas nic napisać. Teraz mam lat czterdzieści cztery, czasu niewiele i gdyby nowe zajęcia miały mi uniemożliwić pisanie — nie mógłbym się ich podjąć w zarozumiałym może złudzeniu, że moje wiersze są ważniejsze.

Poza tym zaangażowałem się tu w robotę wydawania pisma „Tygodnik Polski”, które może widujesz. Nie przeceniam tej sprawy, ale dalsze jej normalne funkcjonowanie też w dużym stopniu ode mnie zależy — puścić to mógłbym tylko, będąc naprawdę i bardzo potrzebny gdzie indziej.

\footnotetext{
${ }^{34}$ Najpewniej była to dedykacja na wydanej w 1942 Lutni po Bekwarku, którą częściowo zacytował Morawski we wspomnieniu pisanym po śmierci Lechonia.

${ }^{35}$ Odczytanie prawdopodobne; wolno przypuszczać, że jest tu mowa o gen. Sikorskim, który wcześniej powołał Morawskiego na ambasadora nadzwyczajnego i posła pełnomocnego RP przy Komitecie Wyzwolenia Narodowego; funkcję tę nominowany objął w październiku 1943.

${ }^{36}$ (franc.) — Mój Drogi Ambasadorze i Przyjacielu.
} 
Powiem szczerze i zarozumiale, że wiem, iż przedstawiam dla placówki w Algierze pewną wartość. Jest nią po prostu to, że zmuszony w Rio i tutaj napisać parę rzeczy po francusku, zostałem uznany przez znawców ni mniej ni więcej tylko za doskonałego, czy jak mówi Geneviève Tabouis ${ }^{37}$ „,wielkiego pisarza francuskiego”. Nie tylko nie muszę się tu napraszać, aby coś wydrukowano, ale Francuzi sami mnie proszą. Tak mnie to samego dziwi, że piszę Ci to bez żenady — że niemal łatwiej mi się pisze prozą po francusku niż po polsku. Gdybym to wszystko miał okazję uzyskać dla Polski w Algierze i ,porywać” naród, byłoby to oczywiście coś.

Druga rzecz to parę ,stosunków” teraz ważnych a dawnych — jak bardzo przyjacielski stosunek z Ministrem Informacji Henri Bonnetem i jego żoną ${ }^{38}$, z Gustawem Palewskim $^{39}$, dyrektorem gabinetu de Gaulle'a; mówię o rzeczach najważniejszych, nie licząc tych znajomości, które bym odnalazł na miejscu i z którymi dałbym sobie radę, o ile to jest w tej chwili w ludzkiej mocy.

I wreszcie: znam sprawy francuskie z najważniejszego teraz dla nich punktu to znaczy się z Waszyngtonu. Uważam, że stosunki polsko-francuskie tutaj w znacznej mierze układają się i bez stałego kontaktu Algieru (polskiego) z Waszyngtonem nic naprawdę na większą skalę zrobić się nie da w tej tak skomplikowanej i tyle jeszcze w przyszłości obiecującej niespodzianek i [---] sprawie.

Nikt chyba w Londynie nie ma złudzeń, jak niezwykle ciężka, jak chwilami dramatyczna będzie nasza sytuacja w Algierze, nie mówiąc o tej, która się musi stworzyć po przyjeździe do metropolii; mam wrażenie, że wszystko jest do pomyślenia najgorszego, od Wielkiej Rewolucji Francuskiej poczynając; nie bardzo nas będą wtedy słuchali.

W związku z tym absolutnie nie mógłbym się podjąć prowadzenia prasy — bo primo prawdopodobnie ogranicza się ona do bardzo niewielkich rzeczy, po drugie będzie ona jak nigdy dyktowana z góry i nieraz bardzo zła. W praktyce mógłbym jako w pewnej mierze ,specjalista” tym odcinkiem też się zająć, ale nie mógłbym przyjąć stanowiska, obarczającego mnie za to i tylko za to odpowiedzialnością. Gdybym więc miał jechać, pojechałbym tylko jako jeden z „normalnych” radców, tym więcej, że jako urzędnikowi i człowiekowi [---] należy mi się to stanowczo. Sądzę, że jeżeli nie macie już z góry ustalonych planów, byłoby może najsłuszniej dopiero po przyjeździe Twoim do Algieru zorientować się, czy taki „radca” jak ja jest tam naprawdę potrzebny. Ja

${ }^{37}$ Geneviève Tabouis (1892-1985), pisarka i dziennikarka francuska, autorka m.in. historyczno-literackich biografii królów Nabuchodonozora i Salomona, faraona Tutenchamona oraz książek na bieżące tematy polityczne. Lechoń był z nią zaprzyjaźniony od czasów paryskich.

${ }^{38}$ Henri Bonnet (1888-1978) i jego żona Hellé (z domu Zervoudaki, z pochodzenia Greczynka) byli bliskimi znajomymi Lechonia z okresu przedwojennego w Paryżu, później utrzymywali kontakty towarzyskie w Nowym Jorku. W 1921-1931 Bonnet był członkiem sekretariatu Ligii Narodów; w czasie wojny pełnił funkcję ministra informacji we Francuskim Komitecie Wyzwolenia Narodowego i jesienią 1944 w Tymczasowym Rządzie Republiki Francuskiej, następnie w 1944-1954 był ambasadorem Francji w Stanach Zjednoczonych.

${ }^{39}$ Gaston Palewski (1901-1984), francuski polityk polskiego pochodzenia; od lat 30. zwolennik poglądów politycznych i wojskowych gen. Ch. de Gaulle'a; po wybuchu drugiej wojny światowej walczył w lotnictwie francuskim, po klęsce Francji przedostał się do Londynu i dołączył do de Gaulle'a, formującego Siły Wolnej Francji, którymi następnie dowodził w 1941 we wschodniej Afryce. W 1941 został w Londynie szefem gabinetu de Gaulle'a we Francuskim Komitecie Narodowym, z którym w 1943 przeniósł się do Algieru, a w 1944 do wyzwolonego Paryża. Po wojnie był jednym z głównych rzeczników gaullizmu i współzałożycielem partii gaullistowskiej. W 1951 został wybrany do Zgromadzenia Narodowego, a w 1953-1955 był jego wiceprzewodniczącym. Po upadku rządów de Gaulle'a wycofał się z czynnej polityki. W 19751974 przewodniczył Radzie Konstytucji Francji. 
muszę przede wszystkim myśleć o swym pisaniu i choć osobiście wszystko mnie ciągnie do Algieru, muszę kazać tym sentymentom zamilknąć, aby coś po mnie pozostało poza korespondencją w MSZ. Ty, Mon Cher Ambassadeur et Ami, najlepiej będziesz wiedział, powąchawszy tamtejszego powietrza, czy nie zabije ono autora, którego zawsze darzyłeś swoją pobłażliwą życzliwością. Oczywiście jednak nie mam prawa i nie chcę odmawiać rządowi tych usług, które naprawdę byłyby ważne i w których mógłbym być niezastąpiony. Sądzę, że nic na tym dobro sprawy nie straci, jeśli ta rzecz przejdzie przez Twoją lustrację „w terenie”. Ja tutaj czasu nie tracę, nie tylko pisząc, ale i ucząc się też zupełnie dotąd obcego świata i nieznanych ludzi. To też ma swoje znaczenie i ponieważ tutaj też brak jest wielki takich, co z ludźmi umieją mówić, więc „pochlebiam sobie”, jak mówi Pan Pickwick, że poduczywszy się angielskiego, mógłbym i tu być przydatny. Zresztą naprawdę wierzę, że teraz parę zadań dyplomatycznych powinni wziąć na siebie poeci i gdyby Rzeczpospolita posłała mnie jako posła z Rządem Jugosłowiańskim, zrobiłaby dobry interes.

Mój drogi! Bardzo Cię przepraszam za wszystko: za zwłokę w odpowiedzi (pamiętasz aforyzm Knolla ${ }^{40}$ : „Po to wstąpiłem do dyplomacji, a nie do straży ogniowej”), za ręczne pismo, za szczerość, za bezczelność. Błagam Cię w imię przyjaźni, przełóż moją niechlujną prozę na język, w którym moja odpowiedź może być podana Ministrowi Romerowi $^{41}$, któremu jak i Tobie najgoręcej dziękuję za zaufanie. Najmocniej Cię ściskam i ż y c z ę é $^{42}$ wszystkiego najlepszego na tej tak bardzo ważnej i tak ,wojennej” placówce. Rozważ i osądź. Basię ${ }^{43}$ błogosławię.

\section{Jan Lechoń}

7.

Telegram Szyfrowy Przychodzacy: z Polconsul - New York do Ministerstwa Spraw Zagranicznych, wystany 20 września 1943, otrzymany 22 września 1943; opatrzony numerem 133; maszynopis na drukowanym formularzu.

Na dokumencie u góry odręczne dopiski: pers. L. 14, Lechoń.

Receptus Nr 154 [tu odręczny dopisek] (pers. L. 14).

${ }^{40}$ Roman Knoll (1888-1946), polityk, dyplomata, wolnomularz; od 1908 działał w organizacjach niepodległościowych; w 1920 jako ochotnik brał udział w wojnie polsko-bolszewickiej, następnie pełnił funkcję sekretarza delegacji polskiej podczas rokowań z Rosją Sowiecką w Rydze. W latach 1921-1923 stał na czele poselstwa polskiego w Moskwie i w 1924-1926 w Ankarze. Po przewrocie majowym 1926 został mianowany wiceministrem spraw zagranicznych; pełnił też funkcję posła polskiego w Rzymie (1926-1928) i w Berlinie (1928-1931). Po objęciu MSZ przez ministra J. Becka odszedł z dyplomacji. W czasie drugiej wojny światowej był Szefem Spraw Zagranicznych Delegatury Rządu na Kraj. Jego powiedzenie cytowane jest w wielu wspomnieniach z okresu międzywojennego, gdy była mowa o potrzebie kontaktu na wypadek ewentualnych pilnych spraw do załatwienia (,nie po to wstąpiłem do dyplomacji, a nie do straży ogniowej, żeby mieć pilne sprawy”).

${ }^{41}$ Tadeusz Romer (1894-1978) piastował tekę ministra spraw zagranicznych od 14 lipca 1943 do 24 listopada 1944. Dyplomata, sekretarz delegacji polskiej na konferencję pokojową w Paryżu. Od 1919 w MSZ (w 1935-1937 poseł w Lizbonie, w 1937-1941 ambasador w Tokio, w 1942-1943 ambasador w Kujbyszewie); po wojnie wyjechał do Kanady, gdzie był wykładowcą na McGill University w Montrealu.

${ }^{42} \mathrm{~W}$ oryginale podkreślone.

${ }^{43}$ Mowa o córce Morawskiego; zob. przyp. 4. 
Lechoń poinformowany. Nie chciał odpowiadać telegraficznie i wysłał list kurierem do Ambasadora Morawskiego.

$$
\text { Polconsul }^{44}
$$

8.

Pismo Tadeusza Romera, opatrzone pieczęcia Ministerstwa Spraw Zagranicznych w Londynie i symbolem Nr Pers/L-14/43, do Jana Lechonia w Nowym Jorku; maszynopis.

Londyn, dnia 23 września, 1943.

Przydzielam Pana z dniem 1 września 1943 r. do Przedstawicielstwa Rządu R.P. przy Francuskim Komitecie Wyzwolenia Narodowego w Algierze i powierzam Panu pełnienie funkcji Radcy Prasowego.

\section{Minister \\ Tadeusz Romer [podpis odręczny]}

Do Pana

Jana Lechonia

W New Yorku

Otrzymuje do wiadomości:

Pan Ambasador Morawski

P.I., A.II., A.IV.

\section{9.}

Telegram Szyfrowy Odchodzacy: do Polconsul New York z Ministerstwa Spraw Zagranicznych, datowany 8 października 1943; opatrzony numerem 207; maszynopis na drukowanym formularzu. Na dokumencie u góry odręczne dopiski: pers. L. 14, Lechoń.

Dla Lechonia. List otrzymałem. Pod względem formalnym stanowisko odpowiada Pańskim życzeniom, ponieważ nominacja na radcę nastąpi z ramienia MSZ, a nie Ministerstwa Informacji i Dokumentacji. Warunki pracy postaram się zapewnić jak najdogodniejsze. Ponieważ zadania w A. są bardzo nagłe, prosiłbym o jak najszybszy przyjazd, na wypadek zaś zupełnej niemożności — o odwrotną telegraficzną wiadomość.

Morawski

${ }^{44}$ Konsulem Generalnym RP w Nowym Jorku był wówczas Sylwin Strakacz (1892-1973), dziennikarz dyplomata; w 1918 rozpoczął pracę w MSZ; od 1920 był osobistym sekretarzem I. J. Paderewskiego. Przez pewien czas był redaktorem naczelnym „Rzeczpospolitej” (należącej do Paderewskiego), korespondentem „ABC”, nadzorował m.in. spółkę akcyjną Hotel Bristol (będącą własnością Paderewskiego). Uczestniczył w tworzeniu opozycyjnego Frontu Morges. Po wybuchu drugiej wojny światowej był łącznikiem pomiędzy Paderewskim a rządem gen. Sikorskiego oraz stałym delegatem RP przy Lidze Narodów w Genewie. Po śmierci Paderewskiego został mianowany konsulem w Nowym Jorku i pełnił tę funkcję do czasu cofnięcia przez USA uznania rządowi polskiemu na uchodźstwie w lipcu 1945. 
10.

Telegram Szyfrowy Odchodzacy: do Polmission Algier [Ambasada RP w Algierze] z Ministerstwa Spraw Zagranicznych, datowany 19 listopada 1943; opatrzony numerem 17; maszynopis na drukowanym formularzu.

Na dokumencie u góry odręczny dopisek: pers. L. 14.

Czy Pan Ambasador otrzymał definitywną odpowiedź od Lechonia, który podobno nie chce opuścić Ameryki. Obsadzenie stanowiska radcy prasowego uważam za bardzo pilne.

Frankowski ${ }^{45}$

11.

Telegram Szyfrowy Przychodzacy: z Polmission Algier do Ministerstwa Spraw Zagranicznych, wystany 22 listopada 1943, otrzymany 24 listopada 1943; opatrzony numerem 37; maszynopis na drukowanym formularzu.

Na dokumencie u góry odręczne dopiski: Pers. 591, L. 14, Lechoń.

Proszę zażądać od Lechonia ostatecznej telegraficznej decyzji. W razie jego odmowy lub niemożności zastąpienia go Jarkowskim ${ }^{46}$, wołałbym nie obsadzać stanowiska radcy prasowego człowiekiem, który by musiał dopiero wyrabiać sobie stosunki. Akcję prasową oparłbym raczej w takim wypadku na pracy korespondentów PAT'a oraz o ile możności drugiego dziennikarza (Refero nasz 25), a w części oficjalnej powierzyłbym Sobańskiemu ${ }^{47}$. Zamiast radcy prasowego prosiłbym wówczas o przydział do Ambasady jeszcze drugiej pomocniczej siły ref.

Spośród kandydatów wymienionych w naszym telegramie 28, najlepiej pani Dziadulskiej obok Chudzyńskiego lub Staszewskiego.

Propozycje moje, oszczędniejsze budżetowo, czynię na podstawie ustalenia metod pracy dostosowanych do specjalnych warunków terenu. Propagandą zajmujemy się tu wszyscy, odczuwamy natomiast najsilniej potrzebę pomocy w redakcji francuskiej, tłumaczeń i szyfrów.

Morawski

Nad tekstem, opatrzona nieczytelnym podpisem, odręczna notatka:

Czekamy na odpowiedź z Waszyngtonu do dn. 6.XII.

\footnotetext{
${ }^{45}$ Feliks Frankowski (1892-1963), dyplomata; w 1926-1939 był radcą poselstwa i ambasady RP w Paryżu i Vichy, w 1940-1943 przedstawicielem RP przy Komitecie Wolnej Francji i Francji Walczącej, w 1943-1945 sekretarzem generalnym MSZ w Londynie.

${ }^{46}$ Wymienieni w tym telegramie: Jarkowski, Dziadulska, Chudzyński, Staszewski — to zapewne pracownicy MSZ w Londynie; bliższych danych biograficznych nie udało się ustalić.

${ }^{47}$ Najpewniej chodzi o Władysława Sobańskiego (1877-1943), polityka i dyplomatę; w latach 1919-1924 był posłem nadzwyczajnym i ministrem pełnomocnym z ramienia Polski w Belgii i Luksemburgu, w 1924-1927 te same funkcje sprawował w Hiszpanii i Portugalii; odznaczony francuską Legią Honorową III klasy, belgijskim Orderem Leopolda I klasy, Orderem Korony i Orderem Luksemburskim.
} 
12.

Telegram Szyfrowy Odchodzacy: do Polmission Waszyngton z Ministerstwa Spraw Zagranicznych, datowany 29 listopada 1943; opatrzony numerem 815; maszynopis na drukowanym formularzu.

Na dokumencie u góry odręczny dopisek: pers. L. 14.

Proszę odwrotnie telegrafować, czy Lechoń zgadza się jechać zaraz do Algieru. Brak odpowiedzi w ciągu dziesięciu dni będziemy uważać za odmowę.

Frankowski

13.

Telegram Szyfrowy Przychodzacy: z Polmission - Washington do Ministerstwa Spraw Zagranicznych, wystany 2 grudnia 1943, otrzymany 3 grudnia 1943; opatrzony numerem 671; maszynopis na drukowanym formularzu.

Na dokumencie u góry odręczny dopisek: pers. L. 14.

Receptus Nr 815 [tu odręczny dopisek] pers. L. 14

Lechoń zawiadamia, że nie może wyjechać, gdyż z powodu cofnięcia przez Ministerstwo Informacji i Dokumentacji subwencji dla „Tygodnika Polskiego” musi załatwić sprawę dalszej egzystencji tego pisma.

Może wyjechać do Algieru po załatwieniu tych spraw.

Ciechanowski

\section{"LECHOŃ IN ALGERIA"-ABOUT A CERTAIN (UNFULFILLED) DIPLOMATIC ROLE}

This paper is based on the unknown up to this point documents of the Ministry of Foreign Affairs of the Polish Government in Exile from 1943. It shows the authorities efforts to engage Jan Lechon in the activity of Polish diplomacy by the French National Committee for Freedom chaired by gen. Ch. de Gaulle in Algeria. In this situation the poet's experiences on the post of cultural attaché at the Polish Embassy in Paris before the war play a key role. The article reports the poet's political views, his political and propagandistic activity in the circle of Polish émigré in the US as well as his personal feelings towards the government's proposal and arguments which finally made him decide to give up this post.

KEY WORDS: Jan Lechoń; Kajetan Dzierżykraj-Morawski; World War II; Polish diplomacy during World War II; Polish culture and literature during World War II. 